\title{
Diversity of Invertebrate Epifaunas Associating with Mangrove In Balangdatu Village Tanakeke Islands of South Sulawesi
}

\author{
Crisnawati, Magdalena Litaay, Dody Prisambodo, and Slamet Santoso
}

Department of Biology, Faculty of Mathematics and Natural Sciences, Hasanuddin University, Makassar, Indonesia

\begin{abstract}
Research on the diversity of invertebrate epifaunas associating with mangroves in the Balangdatu village of Tanakeke regency, Takalar district, South Sulawesi, has been conducted from September to December 2016. The objective of this research was to know the diversity of invertebrate epifaunas associating with mangrove in Balangdatu Village of Tanakeke Islands. Sample collection was done by using explorative quantitatively plot methods with size $2 \times 2 \mathrm{~m}$, applied at three different stations. Data analysis includes calculation of Absolute density, Uniformity Index (Shannon-wiener), Dominance Index, and Distribution Index. The results showed that there were 13 species of epi fauna of 9 tribes, namely Littoraria $s p 1$, Cerithidea cingulata, Littoraria $s p 2$, Littoraria pallescens, Episesarma sp, Saccostrea cucullata, Pagurus $\mathrm{sp}$, Terebralia sulcata, Cerithidea sp, Nerita planospira, Nisto histrio, Littoraria scabra, and Cassidula vespertilionis. The highest density was found in Littoraria scabra with a density of $0.72 \mathrm{ind} / \mathrm{m}^{2}$. Diversity indices are low which indicate depressed environmental conditions. Distribution Index values across stations $<1$ indicating that the pattern of individual dispersion tends to be uniform.
\end{abstract}

\section{Article History}

Received 5 May 2017

Accepted 15 July 2017

\section{Keyword}

Diversity, Marine

Invertebrates,

Mangrove,

Balangdatu,

Tanakeke.

\section{Introduction}

Mangrove ecosystem is an ecosystem that is strongly influenced by water conditions that change at any time. It has an effect on the living water biota associated with the mangrove ecosystem. Yuniarti (2007) stated that coastal areas are productive maritime environment that can be used directly or indirectly. Potential mangroves as a source of nutrients for biota living is as a residence, feeding ground, nursery ground and spawning ground. Adamy (2009), states that many benthic faunas are associated in mangrove forests, of which has important economic value.

Mangrove ecosystems provide a good habitat for the colonization of various fauna such as shade, moist basic substrate, tree as a sticking point and most importantly the 
abundance of organic detritus as food source (Rangan, 2010). Thus, the mangrove ecosystem has very big influence for the survival of every mangrove fauna.

Many living fauna attach themselves to mangrove plants, but the attachment can cause serious problems because it can inhibit the survival of mangroves. The invertebrate epifaunas are barnacles, oysters, crabs and other invertebrate groups. Barnacle can be a big problem for mangroves because barnacles release the sticking liquid that can be bad for mangrove. Barnacle can create stress of mangrove plants that hamper the process of photosynthesis which should be a source of food for all living creatures (Tapilatu and Pelasula, 2012).

Information on the ecology of invertebrate epifaunas in mangrove forests, especially Tanakeke Island is indispensable in efforts to manage mangrove biological resources. However, the availability of this information is still very limited. Therefore, a research is done entitled the diversity of invertebrate epifaunas that is associated with mangrove in the coastal area of Balangdatu village of Tanakeke Islands, Takalar Regency, South Sulawesi.

\section{Materials and Methods}

\section{Tools and Materials}

The tools used in this research are nylon rope, chisel, scissors, plastic sample, roller meter, stationery, digital camera, underwater camera, plot size $2 \times 2 \mathrm{~m}$, thermometer, bootish, permanent marker, loop (magnifying glass), Box, identification book, Global Positioning System (GPS), hand refractometer, DO-Meter, pH-Meter. Materials used in this study including $70 \%$ alcohol substrate, label paper and sample of invertebrate epifaunas.

\section{Research Methods}

The research method used is the transect method combination plot. Data collection was done by purposive sampling method using quadratic transect.

\section{Description of Research Location}

The research area was located in Balangdatu Village, Mappakasunggu District, Tanakeke Islands, Takalar District, South Sulawesi. Geomorphologicaly, Tanakeke is an archipelago consisting of several islands linked to the expanse of mangrove forest, the total land area of Tanakeke Islands reaches $8.37 \mathrm{~km}^{2}$ (Nurdin, 2014). The sampling point consists of 3 (three) stations (Figure 1). Station (1) one located in the urban area of Cambangloe located near the residential population with sandy mud substrate. Station 2 (two) is located in Balangloe urban area located near pond with mangrove condition which partially logged. Station 3 (three) is located in Bungung lompoa urban area which is close to seaweed cultivation with mangrove condition that there is planting activity.
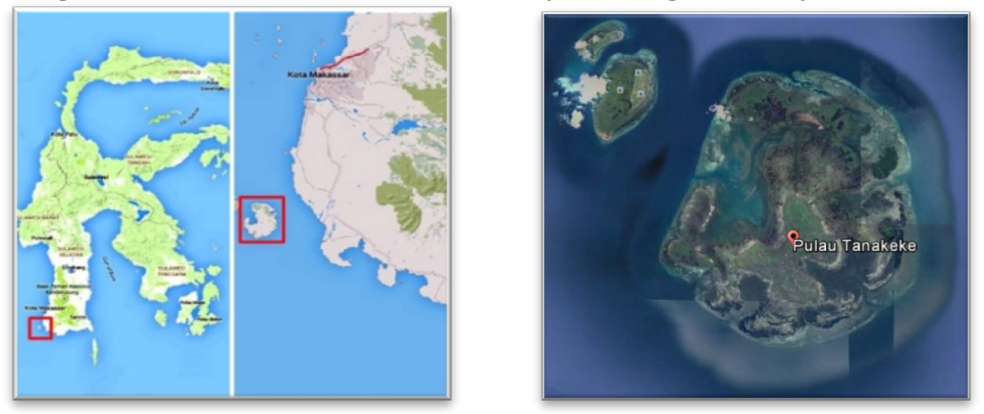

Figure 1. Map of Tanakeke Island, Takalar District, South Sulawesi.

(Source: Google Earth, 2016) 


\section{Work Procedures}

The data were collected by purposive sampling method (transect quadrate) at three stations by hand on plot size $2 \times 2 \mathrm{~m}$ with transect length $100 \mathrm{~m}$. The samples of encapsulated epifauna were inserted into plastic clip differentiated between those found in roots, stems, and Mangrove leaves. The samples were then washed and preserved using $70 \%$ alcohol then taken to the laboratory for identification and analysis.

\section{Sample Identification}

The samples, that had been preserved using 70\% alcohol, were then identified by observing morphological characteristics based on Dharma reference (2005). The identification was conducted at the Laboratory of Environmental and Marine Sciences, Department of Biology, Faculty of Mathematics and Natural Sciences, Hasanuddin University.

\section{Oceanographic Parameters}

Environmental parameters included temperature, salinity, $\mathrm{pH}$, Dissolved Oxygen (DO) and substrate were recorded during field campaign.

\section{Data Analysis}

The collected species of invertebrate epifaunas were identified by using an identification book according to Dharma, 2005. Data of invertebrate epifaunas were then analyzed by using absolute density formula, index of species diversity, uniformity index, dominance index, and distribution index/distribution type.

\section{Results and Discussion}

The identification of invertebrate epifaunas revealed that there are 13 species of 9 families consisting of two phylum namely phylum molluska and arthropoda. The species of invertebrate epifaunas found in the three research stations are generally gastropod species, only a few species of crustaceans and bivalves, a total of 13 species found among them are in station 1, as many as 12 species, in station 2 are 11 species and at station 3 are 7 Types (Table 1).

Table 1. Species Composition of Invertebrate Epifaunas Found in Balangdatu Waters

\begin{tabular}{|c|l|c|c|c|c|}
\hline No & \multicolumn{1}{|c|}{ Species } & ST 1 & ST 2 & ST 3 & $\begin{array}{c}\text { Total No of } \\
\text { Ind/Species }\end{array}$ \\
\hline 1 & Littoraria sp 1 & $\mathrm{V}$ & $\mathrm{V}$ & - & 44 \\
\hline 2 & Cerithidea cingulata & $\mathrm{V}$ & $\mathrm{V}$ & - & 50 \\
\hline 3 & Littoraria sp 2 & $\mathrm{V}$ & $\mathrm{V}$ & - & 19 \\
\hline 4 & Littoraria pallescens & $\mathrm{V}$ & $\mathrm{V}$ & $\mathrm{V}$ & 75 \\
\hline 5 & Episesarma sp & $\mathrm{V}$ & $\mathrm{V}$ & $\mathrm{V}$ & 48 \\
\hline 6 & Saccostrea cucullata & $\mathrm{V}$ & - & $\mathrm{V}$ & 22 \\
\hline 7 & Pagurus sp & $\mathrm{V}$ & - & - & 38 \\
\hline 8 & Terebralia sulcata & $\mathrm{V}$ & $\mathrm{V}$ & $\mathrm{V}$ & 22 \\
\hline 9 & Cerithidea sp & $\mathrm{V}$ & $\mathrm{V}$ & $\mathrm{V}$ & 119 \\
\hline 10 & Nerita planospira & $\mathrm{V}$ & $\mathrm{V}$ & $\mathrm{V}$ & 16 \\
\hline 11 & Nerita histrio & $\mathrm{V}$ & $\mathrm{V}$ & - & 18 \\
\hline 12 & Littoraria scabra & $\mathrm{V}$ & $\mathrm{V}$ & $\mathrm{V}$ & 189 \\
\hline 13 & Cassidula vespertilionis & - & $\mathrm{V}$ & - & 4 \\
\hline
\end{tabular}

Note: - = absent $\mathrm{V}=$ present 


\section{Absolute Density}

The observations showed absolute density with different ranges in Station I with the number of fauna species observed attached to the ${ }^{2}$ nd root, $72 \mathrm{ind} / \mathrm{m}^{2}$ on stem $0.96 \mathrm{ind} / \mathrm{m}^{2}$ and on leaves $0.49 \mathrm{ind} / \mathrm{m}^{2}$. Meanwhile, in the station $\mathrm{II}$, the number of observed fauna attached at the root is $1.79 \mathrm{ind} / \mathrm{m}^{2}$, on the stalk is $0.78 \mathrm{ind} / \mathrm{m}^{2}$ and on leaves is $0.29 \mathrm{ind} / \mathrm{m}^{2}$ and at station III with the number of individuals attached to the roots is $1.43 \mathrm{ind} / \mathrm{m}^{2}$, on stem is $0.17 \mathrm{ind} / \mathrm{m}^{2}$, and on leaves is $0.40 \mathrm{ind} / \mathrm{m}^{2}$. Based on these data the number of epifauna found more in the roots and stems of mangrove plants compared to the leaves. The absolute density data found in each station research area was $3.35 \mathrm{ind} / \mathrm{m}^{2}$, while the number of individual with the lowest densities was found in station 3 with the density of $2.13 \mathrm{ind} / \mathrm{m}^{2}$.

\section{Index of species diversity $\left(\mathrm{H}^{\prime}\right)$}

The results showed that the diversity of epi fauna species is low due to the ecosystem condition has been disturbed by the existence of human activities in the area, such as logging conducted in mangrove forests to be used as firewood, waste is thrown into the waters, so that the research station obtained the number of species diversity ranged Between 1.33 to 1.87. This result corresponds to Abbas, A.A.'s observations. (2015), states that the value of low biodiversity is due to the influence of human activities in the study sites. Furthermore, Arbi (2008), states that the high value of species diversity can be caused by the number of species or individual fauna obtained in abundant amounts than other types. Three important ecosystems in coastal areas are sea grass beds, coral reefs and mangrove forests that are the main habitat of almost all aquatic fauna.

According to Brower et al. (1990), all computed values have a biodiversity value of less than $2(\mathrm{H}<2)$. This condition shows low species diversity which means low community stability and water conditions have been disrupted.

\section{Uniformity Index (E)}

The results showed stable category with index values ranging from 0.57 to 0.75 stable community means that the spread of individual fauna is relatively same or uniform although the type of gastropod is greater than the other types. The existence of relatively uniform environmental conditions allows balance distribution of epi fauna species primarily in the mangrove ecosystem Balangdatu village. In the research of Yulianti (2013), in Marabombang waters of Pinrang regency of South Sulawesi stated that the result of data analysis of epi fauna from gastropod type ranged from 0.37-0.56. Moreover, Pratiwi (2009), reported that in the mangrove area of Delta Mahakam, East Kalimantan the value of uniform index of type of epi fauna of crustaceans species ranged from 0.53-2.02 which illustrated that the distribution of epi fauna in the area was relatively the same or evenly distributed.

\section{Index of Dominance (C)}

The result of data analysis on epi fauna shows the value of dominance index ranged from $0,19-0,34$. This index value belongs to low category and shows that at research station there is no dominance of certain type of epi fauna or community in stable condition so that there is no certain species which has a high number of indiv. Based on the results of research Nurrudin (2015), in the village of Tungkal I Tanjung Jabung West, the dominance index (C) in each study location ranged from 0.12 to 0.22 indicating that there is no type which dominates in the area although the type of Gastropoda much more but not dominate. In contrast to the results of research Gladys (2013), in the area Tongkeina Manado which has a value of 
dominance index ranged from 0.157-0.350 which means that there are almost no species in this community.

\section{Index of Distribution/Distribution Type (Id)}

The result of data analysis showed that the pattern of dispersion of epi fauna species in mangrove plants in general can be categorized uniformly, with the index value in each research station ranged from 0,52-0,81, in contrast to research of Fitriana (2006), which stated index value of spread in forest Mangrove Ngurah Rai Bali Forest Park especially in research station has the pattern of spreading $(>1)$ that is ranged between 1,584-1,869. This indicates the presence of resources to support organisms that are clumped and unevenly distribute across all observation sites.

According to Brower et al. (1998), if the spread index is less than one $(\mathrm{Id}<1)$ then the dispersion pattern is uniform distribution pattern, if spread index is equal to one $(I d=1)$, then the dispersion pattern is random, whereas if the spread index is more than one (Id> 1$)$, then the dispersion pattern formed is clustered.

Thus it can be concluded that the pattern of epifauna distribution in mangrove plants, especially in the research station located in Balangdatu village tend to be uniform. This pattern of uniform distribution according to (Odum 1993), occurs because of the existence of individual fauna are having competition so that it encourages the division of space evenly.

\section{Environmental Parameters}

The result of measurement of environmental parameters in study area is described in Table 2.

\section{Temperature}

The results of the measurement and analysis of water samples at the study sites showed a temperature range between $30-32^{\circ} \mathrm{C}$, this range is still feasible for the life of epifauna which can generally live in a wide temperature range. According to the Ministerial Decree No. 51 year 2004 air quality / air temperature in mangrove area with natural category ranged between $28-32^{\circ} \mathrm{C}$. While based on research conducted by Litaay et al. (2014) conducted in mangrove area of Bontolebang waters of Selayar regency of South Sulawesi, the result of temperature measurement at each station showed the same range ranging from 31$38^{\circ} \mathrm{C}$ the range is still feasible for the life of the sticking fauna such as molluscs this is due to the morphological form of the epi fauna that has the shell.

\section{Salinity}

The result of measurement of water samples at each research station obtained salinity range between $25-30 \%$ oo, salinity range in mangrove area in each research station is good for mangrove growth and organism living in the area. This is in accordance with the Decree of the Ministerial Decree No. 51 year 2004, which stated salinity in mangrove area with natural category ranged from 30-34 \% \% . While the results of research conducted by Muhsin (2016), salinity value in the mangrove area of Kendari gulf, especially at the research station that range from $29.5-30 \%$ o.

\section{Degree of Acidity (pH)}

The result of data analysis of $\mathrm{pH}$ value showed at all stations ranged from 7,9-8,3. The value is categorized appropriate and it still supports the life of organism, especially epifauna 
at research location in mangrove area of Balang Village of Tanakeke archipelago of Takalar Regency. Ennawati et al., (2013) reported that $\mathrm{pH}$ value in mangrove forest of Tongke-Tongke village, Sinjai Regency ranged between 7,40-8,08.

\section{Dissolved Oxygen (DO)}

The result of dissolved oxygen (DO) concentration in each station is quite high (> 5 $\mathrm{mg} / \mathrm{L}$ ) which is between 7,7-8,2 so that it can support the life of the aquatic organism. This is in accordance with the Regulation of the Minister of Environment No. 51 year 2004, dissolved oxygen content in mangrove area with natural category that is more than five (> $5 \mathrm{mg} / \mathrm{L}$ ). While research conducted by Adamy (2009) the average Dissolved oxygen of waters in Panimbang coastal mangrove habitat ranged between $7,13-7,36 \mathrm{mg} / \mathrm{L}$.

\section{Substrate Characteristics}

Substrate conditions at research stations in three locations consisting of Cambangloe, Balangloe and Bungunglompoa have substrate quality of sandy mud in the bottom of the sea. This indicates that the basic substrates present in the three research stations can still support the mangrove growth activity and biota life that exist on the island, in accordance with the statement of Bengen (2004), mangrove generally grown in intertidal areas of muddy, clay and sandy soils.

Based on research conducted by Kamalia.M (2014), substrate type found at research station is mud and sandy mud found many number of gastropod species so that it can be said that type of substrate is very good for life of gastropod type living in that area.

Table 2. Value of Environmental Parameter

\begin{tabular}{|c|c|c|c|c|c|c|}
\hline \multirow{3}{*}{ Station } & \multicolumn{6}{|c|}{ Environmental Parameter } \\
\hline & \multicolumn{2}{|c|}{$\begin{array}{c}\text { Temperature } \\
\text { (oC) }\end{array}$} & \multirow{2}{*}{$\begin{array}{l}\text { Salinity } \\
\text { (o/oo) }\end{array}$} & \multirow[t]{2}{*}{ pH } & \multirow{2}{*}{$\begin{array}{c}\mathrm{DO} \\
(\mathrm{Mg} / \mathrm{L})\end{array}$} & \multirow{2}{*}{$\begin{array}{c}\text { Substrate } \\
\text { Characteristics }\end{array}$} \\
\hline & Water & Air & & & & \\
\hline A1 & 32 & 28 & 25 & 8,3 & 8,0 & Muddy sand \\
\hline $\mathrm{A} 2$ & 31 & 28 & 25 & 8,3 & 8,0 & Muddy sand \\
\hline A3 & 31 & 26 & 25 & 8,3 & 7,9 & Muddy sand \\
\hline B1 & 32 & 27 & 29 & 8,2 & 7,8 & Muddy sand \\
\hline $\mathrm{B} 2$ & 32 & 29 & 28 & 8,2 & 8,0 & Muddy sand \\
\hline B3 & 31 & 28 & 30 & 8,2 & 7,7 & Muddy sand \\
\hline $\mathrm{C} 1$ & 31 & 29 & 28 & 7,9 & 8,2 & Muddy sand \\
\hline $\mathrm{C} 2$ & 32 & 29 & 28 & 7,9 & 8,2 & Muddy sand \\
\hline C3 & 30 & 28 & 27 & 7,9 & 8,2 & Muddy sand \\
\hline
\end{tabular}

\section{Conclusions}

The study concludes that there are 13 species of invertebrate epifaunas which belongs to 9 families are living on mangrove area of Balangdatu village of Tanakeke archipelago of Takalar regency of South Sulawesi. The index of species diversity in the biological index of each station is low ranging from 1.33 to 1.88 reveals that the mangrove area of Balangdatu village can be categorized as disturbed. 


\section{References}

Abbas.A.A., 2015. Biodiversity of Gastropoda Epifauna in Mangrove Area Bontolebang Waters of Selayar Island Regency, South Sulawesi. Journal Department of Biology. Faculty of Mathematics and Natural Sciences. Hasanuddin University, Makassar.

Adamy, K.M.T., 2009. Association of Pelecypoda and Mangrove Communities in Coastal Area Panimbang Pandeglang Banten Regency. Skripsi. Undergraduate Program Bogor Agricultural University. 1-72.

Arbi, U. Yanu, 2008. Community of Molluscs in the Seagrass of Wori Beach of South Sulawesi. Journal of Bumi Lestari. Page 3.

Bengen. D.G., 2004. Guidelines on Introduction and Management of Mangrove Ecosystem PK SPL-IPB. Bogor.

Brower, J. S., J. H. Zar and N. O., Ende, 1990. Field and Laboratory Methods for General Ecology. Third Edition. Brown.

Dharma, B., 2005. Recent and Fossil. Indonesian Shells. Conchbook. Germany. 424 pages.

Ernawati. SK, dkk., 2013. Succession of Macrozoobentos in Natural Mangrove Forest and Rehabilitation in Sinjai District, South Sulawesi. Bionature. 14(1):49-60.

Fitriana, Y.R., 2006. Diversity and Abundance of Makrozoobentos in Mangrove Forest Rehabilitation Results Ngurah Rai Bali Forest Park. Biodiversitas. 7(1):67-72.

Gladys, L, Saripantung, 2013. Community Structure of Gastropoda in Overflow Seagrass Intertidal Area of Manado City Tongkeina Subdistrict. Scienttific Journal of Platax. 1(3).

Kamalia. M., 2014. Distribution Pattern of Gastropod in Mangrove Ecosystem of Tanjung Ayun Sakti Bestari Hill Subdistrict of Tanjung Pinang City. Journal of Water Resource Management FIKP UMRAH. Tanjung Pinang.

Litaay.M., Darussalam, Priosambodo.D., 2014. Bivalvia Community Structure in Mangrove Area Bontolebang Waters of Selayar Islands Regency of South Sulawesi. Proceedings of Mathematics and Natural Science National Seminar. Bandung.

MNLH. 2004. Decree of the State Minister for the Environment on the Quality of Sea Water. KEP No-51/MNLH/I/2004. 8 April 2004. Jakarta. [In Indonesian]

Muhsin, Jamili, Hendra, 2016. The Vertical Distribution of Gastropods in Rhizophora Apiculata Mangrove Kendari Bay. Journal of Biology Research Mathematics and Natural Sciences. Haluoleo University, Kendari.

Nurdin, Y., 2014. Development Strategy of Tanakeke Islands Mangrove Management Program. Blue Forest Foundation Indonesia. Makassar.

Nurrudin, 2015. Diversity of Gastropoda Type Around Fish Auction Place (FAP) Parit 7 Tungkal I Village of West Tanjung Jabung. Biospecies. 8(2):51-60.

Odum, E. P., 1993. Fundamentals of Ecology. Third Edition. Gajah Mada. [In Indonesian]

Pratiwi.R., 2009. Composition of Crustacean Presence in Mangrove Delta Mahakam East Kalimantan. Journal of MAKARA, SCIENCE. 13(1):65-76.

Rangan, J. K., 2010. Inventory of Gastropoda in Mangrove Forest Floor Rap-Rap Village of South Minahasa Regency North Sulawesi. Journal of Marine Science and Fisheries. $6(1)$.

Tapilatu dan Pelasula, 2012. Associated Fouling Organism with Mangrove In Inner Bay of Ambon. Department of Marine Science and Technology FPIK-IPB. Journal of Tropical Marine Science and Technology. 4(2):267-279.

Yulianti, 2013. Biodiversity of Gastropoda in Marabombang Sea Region of Pinrang Regency, South Sulawesi. Journal of Marine Science and Fisheries. 23(3):167-175. 
Yuniarti, 2007. Management Coastal Areas of Indonesia. (Case Study: Community Based Coral Reef Management in Riau Islands): Kepri. 38 pages. [In Indonesian]

\section{To cite this article:}

Crisnawati, Litaay, M., Prisambodo, D. \& Santoso, S. 2017. Diversity of Invertebrate Epifaunas Associating with Mangrove In Balangdatu Village Tanakeke Islands of South Sulawesi. International Journal of Applied Biology. 1(1):14-21 